\title{
1. African regionalisms: exploring the drivers and actors
}

\section{INTRODUCTION}

The literature on comparative regionalism has grown substantially over the past decades, mainly because of the realization that the European history of regional cooperation and integration is just one among various experiences with regionalism, and that the study of different regionalisms is necessary to overcome the ethnocentric bias that characterizes much social science practice (Acharya 2014: 649-650). In particular the rise of the so-called 'new regionalism' since the beginning of the 1990s has led to increased attention to varying forms of regional order, increasingly also in a comparative perspective.

Many scholars have published on regionalisms in Africa, either at the continental or the sub-regional level, and have thus contributed to our understanding of the specificities of the African context, as well as of how African experiences are similar to those elsewhere. While some scholars have paid attention to the role of asymmetries across African regions and regionalisms (see the earlier discussion in the introductory chapter), current analyses have generally not given much weight to how political, economic and social asymmetries influence regionalisms and, conversely, how patterns of regional interaction impact on asymmetrical development.

In the context of this book, the purpose of this chapter is to offer an overview of the way in which scholarship on comparative regionalism may contribute to an understanding of the drivers of and actors in regionalism and their impact on asymmetrical development in Africa. ${ }^{1}$ We start with a conceptual discussion, which is aimed at distinguishing various notions associated to the discussion of regionalism. The following sections discuss the ontology of regions and regionalisms, and the drivers of and actors in regionalism.

\section{A NOTE ON CONCEPTS}

The comparative regionalism literature applies a series of interrelated concepts with partly overlapping meanings. Hurrell's classical treatment 
of regionalism breaks up the concept into five categories. Hurrell (1995: 39-45) distinguishes among:

- regionalization, which is characterized by the growth of societal integration in a region, as a consequence of the expansion of markets, trade and investment and activities of private companies;

- regional awareness and identity, either as a result of identification with a culture, history or traditions, or in response to external challenges;

- regional interstate cooperation, expressed by interstate or intergovernmental agreements or regimes;

- state-promoted regional integration, with the intention of reducing barriers to the mobility of goods, services, capital or people; and

- regional cohesion, which is the process that leads to the emergence of a cohesive regional unit (Hurrell 1995: 39-45).

Most scholars understand regionalism in a narrower way, and see it as synonymous with one or another form of regional cooperation. In these interpretations, regionalism covers the last three of Hurrell's categories (and is a formal, or de jure, form of cooperation, which involves 'a conscious policy of states or sub-state regions to coordinate activities and arrangements in a greater region' (Wyatt-Walter 1995: 77). In their full breadth, regionalism and regional cooperation denote the whole gamut of possible forms of formal arrangements among political units across national borders. The arrangements may be limited to a particular policy area or may have a broader scope, and their level of institutionalization may vary.

Specific definitions of regionalism, however, differ from author to author, with some placing more emphasis on the process, others on ideas and inspirations and still others on the institutional aspects of regional cooperation. In their seminal definition, Gamble and Payne (1996: 249) include the notion that regionalism is a project undertaken by states aimed at reorganizing political and economic relations in a certain area. Likewise, Bach (2016b: 5) focuses on ideas or ideologies, programmes, policies and goals that seek to transform an identified social space into a regional project . . . associated with institution-building and the conclusion of formal agreements'. Further, he indicates that regionalism 'also refers, under the influence of the constructivist literature, to cognitive and ideational projects associated with the "invention" of regions and construction of identities and delineation of mental maps' (Bach 2016b: 5-6). In a similar vein, Söderbaum (2016b: 3) refers to regionalism as representing 'the body of ideas, values and policies that are aimed at creating a region ... 
[It] usually is associated with a regional project or regional organization'. Börzel and Risse (2016: 7) prioritize institutional aspects and describe regionalism as 'a primarily state-led process of building and sustaining formal regional institutions and organizations among at least three states'.

Usually, regional integration is considered to be a specific sub-category of regionalism. In Börzel and Risse's (2016: 8) understanding, regional integration begins 'when states transfer at least some authority and sovereignty rights to the regional level', and establish a supranational body of some sort. They can do so either in the form of the pooling, or joint exercise, of sovereignty rights (for instance by introducing majority decision-making on certain policy issues), or by delegating part of their tasks to a specialized body.

Since the scholarly literature started to pay attention to so-called new regionalism in the 1990s, scholars have tended to distinguish regionalization from regionalism on analytical grounds, and have generally adopted the meaning that Hurrell attached to the term. Gamble and Payne were among the first to emphasize regionalization as a distinct analytical category, and linked its rise to the policy changes resulting from (neoliberal) globalization. In their words, regionalization is an informal or de facto process, resulting in 'combinations of historical and emergent structures - a complex articulation of established institutions and rules and distinctive new patterns of social interaction between non-state actors' (Gamble and Payne 1996: 250). More recently, the same idea was captured by Vivares and Dolcetti-Marcolini (2016: 5), who describe regionalization as 'an underlying process of formation of regions by means of factual, material and ideational interrelationships between social forces and productive capacities in the societies in question, the flows of individuals and groups, their links and interrelationships, the infrastructure they build, the exchange of goods, services, investments and ideas'.

In a variety of publications, Swedish political scientists Björn Hettne and Fredrik Söderbaum have attempted to develop a joint understanding of the two processes of regionalism and regionalization by coining the concept of 'regionness', which captures different degrees of regional interdependence. The notion of regionness is not solely focused on states and their projects, and thus represents a rejection of the state-centrism that is present in many analyses of regionalism. Regionness, on the other hand, is understood as:

the process whereby a geographical area is transformed from a passive object to an active subject capable of articulating the transnational interests of the emerging region. Regionness thus implies that a region can be a region 'more or less'. The level of regionness can both increase and decrease. (Hettne and Söderbaum 2000: 461) 
Hettne and Söderbaum distinguish various manifestations of regionness, which reflect either an increase in the level of interdependence among actors in a particular geographical space, or a strengthening of political collaboration. The five types (or 'phases') of regionness are (Hettne and Söderbaum 2000: 462-468):

- A 'regional space', which is no more than a distinct geographical zone (or a 'proto-region'), since there is very little interaction among groups living in different parts of the area.

- A 'regional complex', where interdependence has started to grow and there is a certain degree of regionalization visible.

- A 'regional society', which starts to develop when the relations among actors from different parts of the region become more dense and possibly some first expressions of regionalism (in the form of socalled 'micro-regions', cross-border centres of intense interactions) become apparent.

- A 'regional community', when the 'region increasingly turns into an active subject with a distinct identity, institutionalised or informal actor capability, legitimacy and structure of decision-making in relation with a more or less responsive regional civil society, transcending the old state borders' (Hettne and Söderbaum 2000: 466). A regional community can be expected to develop a collective regional identity, which implies that citizens start to identify with the regional entity, possibly in conjunction with the national entities they are part of, and that the division among national units becomes less important.

- A 'region-state', which is considered to be a 'rather hypothetical and perhaps unlikely fifth level of regionness' (Hettne and Söderbaum 2000: 467). Such a region-state would involve the pooling of sovereignty and the establishment of a set of rules on collective decision-making, which make it clear which issues are decided at the supranational, national, local or micro-regional level.

\section{ONTOLOGY OF REGIONS AND REGIONALISM}

In a recent critique of the focus of much academic work on regionalism on the European Union (EU), Amitav Acharya (2016) made an important observation regarding the ontology of regionalism. Building on Appadurai's (2000: 7) distinction between 'trait' and 'process' geographies, Acharya argues that a comparative understanding of regionalism should leave behind its focus on 'conceptions of geographical, civilizational and cultural coherence' (Regional Worlds Project, cited in Acharya 2016: 121), 
which is the hallmark of trait geography. Rather, comparative regionalism should, in his view, conceptualize regions on the basis of a processgeographical perspective, which brings "new ways to approach both space and time in relation to "areas" with space becoming more flexible and porous and time less sequential and cumulative' (Regional Worlds Project, cited in Acharya 2016: 121).

Traditional accounts of so-called 'old regionalism' are representative of the focus on trait geographies. Such accounts tended to picture regionalism mainly as a more or less explicit design aimed at the establishment of regional institutions. In such interpretations of regionalism, the notion of the region was not problematized. Regions were, more or less, taken as a given. Some examples from the early days of the literature on regionalism illustrate this very clearly. Classical notions of economic integration, developed by scholars such as Viner (1950) and Balassa (1962), focused on the different economic arrangements that could be established within a particular region. The ladder of economic integration started with a free trade area and moved up to a customs union, a common market, an economic union and, ultimately, complete economic integration. This approach to economic integration focused mainly on the way in which trade among countries in a region would impact on the countries outside of the region (by applying the twin concepts of trade creation and diversion).

Functionalist and neo-functionalist accounts were applied mainly to regional cooperation and integration in Western Europe. These approaches focused on the countries of the European Community as a well-defined political area. Functionalism and neo-functionalism concentrated on the way in which institutions, created for solving some seemingly technical issue, would generate interdependencies among the countries in a particular region. The sense of enhanced interdependence, coupled with an understanding of the problem-solving capacity of regional institutions, would 'spill over' from the original domain into other policy areas. Thus, the success of functional solutions was felt to generate a demand for deepened cooperation, which would ultimately reach the domain of 'high politics' (Haas 1958; Lindberg 1963).

Classical analyses of regional cooperation broadened the concept beyond economic and functional connotations, and include security issues. Deutsch et al. (1957: 5) used the term 'security community' to identify areas 'in which there is real assurance that the members of that community will not fight each other physically, but will settle their disputes in some other way'. They analysed the coming into being of a security community using two dimensions: integration and amalgamation. Integration was defined as "the attainment, within a territory, of a "sense of community" and of institutions and practices strong enough and widespread enough 
to assure, for a "long" time, dependable expectations of "peaceful change" among its population' (Deutsch et al. 1957: 5). Amalgamation, which was felt to overlap partially with integration, refers to the 'formal merger of two or more previously independent units into a single larger unit, with some type of common government after amalgamation' (Deutsch et al. 1957: 6). The security community that was discussed was limited to the North Atlantic region, where the United States, Canada and European countries were unified in their attempt to protect themselves against the perceived expansionism of the Soviet Union.

Newer manifestations of regionalism, which have come to dominate the contemporary era of globalization (see Grugel and Hout 1999: 4-6), call for an understanding of regionalist projects following the process geography proposed by Appadurai and Acharya. Globalization as understood by Appadurai (2000: 5), as well as many other scholars, has brought about 'a world fundamentally characterised by objects in motion'. This motion has had important implications for the (nation) state, which has been the building block of many analyses of regionalism. In Appadurai's (2000: 5) words, the state is an 'apparently stable object', but it has become characterized increasingly 'by floating populations, transnational politics within national borders, and mobile configurations of technology and expertise'. Because of the dynamics involved in contemporary globalization, we should not 'mistake a particular configuration of apparent stabilities for permanent associations between space, territory, and cultural organisation' (Appadurai 2000: 7). This implies that regional formations should not be understood as fixed or linked to particular geographies, but as changeable political responses to particular economic, social or cultural challenges.

\section{THE DRIVERS OF REGIONALISMS}

Scholars of regionalism have formulated many explanations of what can be viewed as a very complex social and political issue. Analysts of comparative regionalism need to maintain an open mind as to the variety of possible reasons involved in the setting up of regionalist frameworks. In this context, Louise Fawcett (2016: 25-26) has commented very aptly that 'regionalism cannot be reduced to neat theoretical formulas such as intergovernmentalism, functionalism, or constructivism . . Current evaluations of regionalism that adopt such singular perspectives lead to a partial understanding and do not capture its breadth or its historical trajectory'. With a specific view to the scholarship on African regionalisms, four main drivers may be highlighted: material, ideational, political and external drivers. 


\section{Material Drivers}

The material drivers of regionalism have traditionally received much attention in the literature. Mainstream approaches have tended to analyse regionalism generally in relation to the capacity of regionalist frameworks to provide public goods, where the possible efficiency-enhancing effect of such frameworks is placed centrally. Critical and radical scholars have emphasized the political struggles involved in the establishment of regionalist schemes: while many of them focus on the way in which certain interests are served to the detriment of others, some go one step further and stress the role of regionalism as a mechanism to cement unequal relations among countries and enhance capital accumulation.

Traditional economic accounts of regionalism such as Viner's (1950) and Balassa's (1962), which were alluded to above, focused primarily on the centrality of regional frameworks in the expansion of trade among member states and the resulting possibilities for import substitution. Expectations of trade creation were very important in motivating the 'first wave' of regionalism in Africa, the high point of which was in the 1960s and 1970s (Bachinger and Hough 2009: 47-48). The similarity of production structures across Africa and the limited potential for product diversification implied that African intra-regional trade increased only marginally, and regional integration schemes continued to lead a dormant existence. The era of new regionalism, which is connected to the wave of liberalization, deregulation and privatization that impacted upon international trade since the 1980s, gave rise to a 'spatial unbundling' of stages of production (Baldwin 2011: 5), which facilitated the dispersion of production across the world. The material driver for new regionalism is located in the 'trade-investment-services nexus' (Baldwin 2011: 5) that underpins global supply chains. New regionalism is no longer only about the removal of trade barriers, but involves increasingly 'behind-the-border barriers', such as regulatory frameworks and infrastructural facilities, which are necessary to facilitate foreign investment aimed at production in international value chains (Baldwin 2011: 8-11; Ravenhill 2016: 45).

Other accounts of the material drivers of regionalism focus on a variety of factors. Mattli's (1999) approach to the logic of regional integration focused on coordination in the face of collective-action problems and transaction costs. Based on a variety of institutional theories, Mattli (1999: 46) argued that 'regional institution-building may be viewed as an attempt to internalize externalities that cross borders within a group of countries'. In Mattli's view, economic actors may wish to benefit from larger markets when new technologies enlarge the markets beyond national boundaries: firms will try to change existing governance arrangements in order to 
benefit from economies of scale provided by larger markets, while investors will want to reap the benefits from investing abroad in order to access cheaper natural resources or more advantageous factors of production (Mattli 1999: 46). Regionalist frameworks are then seen as institutions that reduce uncertainties and hazards involved in doing business abroad (Mattli 1999: 47).

Scholars from a critical political economy background, who draw their inspiration from neo-Marxism or world-systems theory, tend to emphasize 'deeper' material drivers of regionalism. Such analyses see regional frameworks as regimes that facilitate accumulation processes, driven by local and/or international capital. Chris Dixon's analysis of the 'nested regional division of labour' in Pacific Asia is an example of how regionalist frameworks - such as the Association of South East Asian Nations (ASEAN), the ASEAN Free Trade Area (AFTA) and the Asia-Pacific Economic Cooperation (APEC) - served in the 1990s as instruments that reflected, and facilitated, the 'exploitation of markets, raw materials and cheap labour' (Dixon 1999: 123). In a more recent analysis of regionalism in East Asia, Mark Beeson (2010: 339) stressed how asymmetrical relationships between China and other countries in the region - institutionalized in the China-ASEAN Free Trade Agreement of 2010 - are both an expression of 'complex regional production networks', and an important source of growth for many of the poorer South East Asian countries.

Similar analyses of Africa's political economy tend to highlight the role that South Africa is playing as a regional hegemonic power. Radical scholars stress how South Africa has assumed the position of the 'middleman' that links the regional accumulation regime, focused on extractive resources and markets, to global neo-liberalism. Pádraig Carmody (2012: 236), for instance, has analysed South Africa's role as 'a conduit for globalised and marketised geo-governance in [Sub-Saharan Africa]', which uses the Southern African Development Community (SADC) as an instrument for intensifying intra-regional trade and investment. Patrick Bond (2013: 266) has characterized South Africa as the 'deputy sheriff' that ensures regional stability in Sub-Saharan Africa, using the New Economic Partnership for Africa's Development (NEPAD) as a regionalist instrument. He sees South Africa as an actor of sub-imperialism, which facilitates the access of global capital to 'super-exploitative extractive industries based upon migrant labour' (Bond 2013: 253). In a similar vein, Justin van der Merwe (2016) has emphasized how South Africa's 'government-business-media complex' has been instrumental in the exploitation of minerals and labour in Southern Africa. Zajontz and Leysens (2015: 309) have placed the 'open regionalism' of SADC in the 1990s against the background of 'regional state-business partnerships', which served as proponents of neo-liberal 
norms and policies. In their view, SADC adopted 'a neoliberal regional development paradigm that suggests redistribution and poverty alleviation through growth' (Zajontz and Leysens 2015: 310).

\section{Ideational Drivers}

Next to the possible material drivers of regionalism, many authors have emphasized the ideational drivers of regionalist projects. Constructivist authors, in particular, have argued that ideas, norms and identities play an important role in international politics (see Acharya 2012: 9-10; Börzel 2016: 48). Regions are not understood as fixed or predetermined, but rather as constructs, which come about partly on the basis of the identification of actors with a regional entity. As a consequence of the emphasis on ideational factors, the formation of regions is understood less as an expression of interests or as a reflection of material drivers, and more as a sign of the development of identities. Such identities are not fixed, and may change over time. Identities may be layered, so that, in Acharya's (2012: 10) words, 'national and regional identities can coexist and even complement each other, instead of being mutually exclusive'.

Ideologies play an important role among the ideational drivers of regionalism. Regional identification may be the resultant of particular ideological convictions, such as the idea that cooperation among states in a given region may bring about peace. The notion of 'liberal' or 'democratic' peace stipulates that peaceful collaboration among liberal states may come about in regions dominated by representative democratic governments, which adhere to liberal principles of human rights and are highly interdependent due to intensive trade, financial and interpersonal relations (Draper 2012; Doyle 2005).

In the African context, pan-Africanism has been an important ideology driving regionalism. Originally framed as an ideological movement of Africans against colonial domination, emphasizing the commonalities of all peoples on the continent, contemporary pan-Africanism is characterized by Mkandawire (2011: 31) as 'a movement both for collective selfreliance and the new regionalism'. Thus, pan-African ideology has come to encompass the creation of entities (Regional Economic Communities or RECs) that were considered sub-regional in the past, but are now seen as integral elements of the pan-African project (Asante 1997: 28-31; Bach 2016b: 77-81). The RECs are, then, perceived as the building blocks of a regional African identity, which has a cultural, a political as well as an economic dimension (Mkandawire 2011: 32). 


\section{Political Drivers}

The literature on African regionalism has placed much emphasis on the political motives for the establishment of regional cooperation schemes, and thus political drivers have possibly received more attention than in the case of regionalism elsewhere in the world. Paradoxically, many authors relate the focus on political dimensions of regionalism to the relative weakness of African states (for example, Hartmann 2016: 278). A common element in many analyses is that African states are comparatively weak because they have been the outcome of a process of decolonization rather than a phase of state-building (Mkandawire 2011: 36-38); in Jackson's (1990) terminology, those states are 'quasi-states'. In many cases, sovereignty was handed over by colonial powers to post-colonial rulers instead of it being the result of a deliberate attempt of those rulers to strengthen their power base among the population. Moreover, the identification of citizens with their state has often remained limited: they feel connected to a variety of networks, composed of families, ethnic groups and patronclient systems, which dominate 'weblike societies' and render the state just one actor among many others; and this is not necessarily the actor that exercises the most authority (Migdal 1988: 30-39).

Given the historical background of many African states, many scholars have analysed regionalism in Africa as a political tool for the establishment or strengthening of sovereignty. Regional cooperation schemes are then seen as platforms that illustrate the equality of African states and their rulers, as well as provide evidence that their leadership contributes to the supply of regional public goods. Regionalism is a relatively easy tool for states to demonstrate the mutual recognition of each other's sovereign power, and thus it assists in confirming and legitimizing the role of the states that participate in cooperative regional frameworks. Fredrik Söderbaum (2004: 425-428) and Christof Hartmann (2016: 278) have emphasized the importance of 'sovereignty-boosting regional governance'. According to Söderbaum, it is a mistake to think that all forms of regionalism would require states to give up sovereignty and decision-making authority to supranational institutions: in the case of African regional cooperation schemes, many rulers 'tend to place heavy emphasis on formal and absolute sovereignty - that is, the maintenance of existing borders and the principle of non-intervention in domestic affairs - because it enhances the power of the governing elite and its ability to stay in power' (Söderbaum 2004: 426).

Other analyses of the political drivers of regionalism in Africa have referred to, for instance, the tendency to engage in 'virtual regionalism' (Fanta 2013: 50-51). This interpretation highlights that African states 
are involved in the signing of regional agreements and the establishment of regional organizations, which are similar in form to agreements and organizations elsewhere in the world. This process results in the creation of the symbols of regional cooperation, but there is very little in terms of follow-up and implementation. Regional institutions may issue statements and produce policy documents, but their common projects generally fail to take off and agreements tend to remain dead letters. Thus, rather than leading to further integration of regions, African regionalism is often the source of 'policies of non-integration', since 'African states are particularly wary of the fact that regional organizations can potentially dilute the little power these states have' (Fanta 2013: 46). Connected to this is Ravenhill's (2016: 43) observation that political support for increased openness among non-state actors is often very limited in African countries, which means that the state is frequently not pressurized to respect regionalist frameworks (Solingen and Malnight 2016: 69-70).

Using similar approaches, Mkandawire (2014), Kenfack (2013) and Gibb (2009) have analysed the limited outcomes of regionalism against the background of the political interests represented at the level of the state in Africa. Mkandawire's argument, which is echoed in Kenfack's (2013: 79) analysis of regionalism in Central Africa, focuses on the authoritarian character of government in many African countries. He argues that the claim to authority of authoritarian rulers is intimately connected to the bid for sovereignty. In relation to the possible establishment of genuine regionalist frameworks, Mkandawire (2014: 10) asks the rhetorical question, 'If you are a life president, how do you surrender sovereignty?' In contrast to Mkandawire, Gibb emphasizes the neo-patrimonial character of the African state. He argues that conventional ways of understanding and explaining regionalism - in particular, using indicators of market integration - are flawed, because they fail to understand how 'control of the state equates to control of resources and control over power' (Gibb 2009: 716). Although 'nominal regionalism' is useful because it provides legitimacy, its political drivers will likely prevent it from producing deeper market integration: 'regional integration can only be ... as strong as its constituent parts want it to be (the constituent parts in southern Africa being comprised of neo-patrimonial states)' (Gibb 2009: 717).

Applying the neo-patrimonialist argument in a different way, various scholars have analysed the persistence of so-called 'trans-state regionalization' or 'shadow regionalism' across Africa. In an argument that was developed over several decades, Bach (1999a, 1999b, 2016a, 2016b) points out that social and economic relations in Africa have become regionalized to an important extent. Driven by the desire to maintain existing patronage networks and thereby support their own power bases, transnational 
economic actors make use of cross-border disparities (varying price levels, different regulatory frameworks, and so on) to do business. The activities of the transnational actors potentially lead to a substantial increase of economic and social integration, outside the direct reach of the state and regionalist frameworks (Bach 2016b: 70-75). Trans-state networks lead to a 'domestication' of the state (Bach 2016b: 72), which becomes complicit in the unofficial cross-border activities. The result is an undermining of the regulatory authority of states and of the regionalist frameworks they are part of, because:

trans-state networks often benefit most from an environment that appears uncertain and shifting at the formal level, providing constantly renewed opportunities for arbitrage. The preeminence of networks over policies can also take on exacerbated proportions whenever, as in the eastern DRC [Democratic Republic of the Congo] or Somalia, the exploitation of the 'dividends' of the frontier combines with those advantages that 'entrepreneurs of insecurity' derive from the erosion of state regulatory power and territorial control. (Bach 2016a: 75)

Söderbaum (2004: 428-431) has referred to this collusion between state and non-state actors for the purpose of informal (and often 'illegal') cross-border activities as 'regional shadow governance'. The outcome is an attempt by state and economic elites to maintain existing border disparities and thereby undermine regional organizations (Söderbaum 2004: 429). Christopher Clapham (1999: 59) has analysed this process as the 'politics of the borderland', which has resulted in new patterns of integration and disintegration across Africa.

\section{External Drivers}

The literature on regionalism has traditionally had an interest in the external drivers of regional cooperation. An important factor behind this interest seems to be the impact left by the European experience with regional integration, which has elevated the history of European integration to a benchmark or a model for regionalist experiments elsewhere in the world. External drivers of regionalism may be categorized under two broad headings. On one side, there are approaches that emphasize emulation, diffusion and socialization, some of which are related to constructivist analyses of regionalism. On the other side, one may identify approaches that focus on the promotion of regionalism as a foreign policy tool, where the European Union has been a main actor.

The comparative regionalist literature appears to be divided on the question of the extent to which the European experience has truly influenced 
regionalism in Africa in a normative sense. Some scholars have argued that the EU has been an explicit normative model for African regionalism, for instance related to the establishment of the RECs (Bach 2016b: 81-85; Draper 2012: 68; Lenz 2012: 162-164). Bach, for instance, has argued forcefully that the EU and its institutions were an important source of inspiration for pan-Africanism in the 1990s:

African regional groupings undertook to revise and adjust treaties so as to emulate the developmental and integrative achievements of the EU, then celebrated for its ability to combine deep integration - associated with a group of core countries - with the progressive incorporation, through territorial enlargement, of new members. (Bach 2016b: 81)

Although the EU has become much less popular in Africa due to the disagreements appearing in the negotiations on Economic Partnership Agreements (EPAs) under the Cotonou Agreement, Bach (2016b: 112-113) maintains that newer forms of 'development regionalism' in Africa are still very much inspired by the case of the EU. In his interpretation, this applies both to the treaties and activities of most RECs, but also to the standards that African organizations such as the African Development Bank and the African Capacity Building Foundation use to measure progress on the regionalist agenda.

Next to the scholars who emphasize the influence of the EU as an example for African regionalism stand other analysts who point out that a certain degree of institutional similarities between European and African region-building does not imply that European and African regionalism are one of a kind. On the basis of a comparison of seven key features of regionalism, Fioramonti and Mattheis (2016: 686) conclude that 'Europe and Africa embody two complex examples of regional governance, largely shaped by different logics'. They argue that the commonalities of the two expressions of regionalism do not go much deeper than a certain institutional isomorphism, and that differences relate to, among others, such varied dimensions as the process, membership, leadership and drivers of regionalism (Fioramonti and Mattheis 2016: 685).

The omnipresence of regionalism across the world has brought scholars to pay more in-depth attention to the diffusion of institutional models and policies. Diffusion, defined by Risse (2016: 87) as a process based on 'claims that there are global scripts of what constitute legitimate institutions and that these scripts are emulated across the globe', could be an explanation of the spread of regionalism as a response to common challenges experienced by developing countries. Risse's (2016: 89) typology of diffusion mechanisms differentiates between direct ways of influence (coercion, incentives and sanctions, and norm socialization and persuasion) and 
indirect ones (competition, lesson-drawing, normative emulation and mimicry). Emulation of the European regionalist framework by the RECs across Africa, which was addressed above, is one example of a powerful diffusion mechanism. Further, some authors have referred to the influence of regional epistemic communities, with the United Nations Economic Commission for Africa (UNECA) as a prime example. For example, Piccolino (2016: 14) has pointed out that UNECA was instrumental in the setting up of regional organizations such as the Economic Commission for West African States (ECOWAS); the Commission has remained a main driver for the diffusion of regionalism throughout Africa since the 1970s. More specifically, Adebajo (2016: 61-65) has documented the intellectual and political role of Adebayo Adedeji, who played an important role in developing the strategic thinking of UNECA and the African Union. He referred to Adedeji as 'Africa's most renowned visionary of regional integration', who was important for the expansion of regionalist frameworks (Adebajo 2016: 61). Further, Apuuli (2016: 143) has highlighted the role of the African Union (AU) as 'a vehicle for promoting "African solutions to African problems"'. Part of the AU's approach as a 'norm-setting organization' (Apuuli 2016: 147) was the furthering of regionalism as approach to economic, political and security problems.

One final important mechanism for the diffusion of regionalist frameworks across Africa appears to have been the external policy of the European Union. Various authors have paid attention to the EU's programmes aimed at the spreading of regionalism to former colonies of its member states, which are current partners across the African, Caribbean and Pacific (ACP) area. Risse (2016: 92) emphasizes that the European Commission has been implementing programmes to spread regionalism, using various different mechanisms, from incentives to norm socialization, persuasion and political dialogue. Very clear incentives for African countries include market access in exchange for the establishment of Economic Partnership Agreements, and financial assistance under the European Development Fund.

Other authors have analysed EU-African relations in different terms. Lenz (2012) and Buzdugan (2013) provide analyses of the relationship between the EU and the Southern African Development Community (SADC). Analysing EU-SADC interactions from a 'diffusionist' perspective, Lenz (2012) emphasizes so-called 'spurred emulation'. In his view, policy-makers in the SADC countries have adopted far-reaching market integration objectives and EU-style institutions under the influence of EU-oriented domestic actors and material support from the EU (Lenz 2012: 162-167). Buzdugan's analysis is grounded in a political-economy perspective and emphasizes how the limited sovereignty of the SADC 
countries and their dependence on aid gave the EU much influence to steer the region to adopt a neo-liberal, trade-oriented form of regionalism (Buzdugan 2013: 923-927). In a study of regionalism in West Africa, which is informed by sociological institutionalism, Piccolino argues that regionalist frameworks are shaped by 'normative emulation' of EU-like institutions. This implies that frameworks 'are created to conform to successful models of organization that are considered legitimate, and their behaviour is driven by a concern for legitimacy rather than a preoccupation with efficiency' (Piccolino 2016: 24). The dependence on aid from the EU provides, in her view, an important impetus for institutional isomorphism. Finally, Ribeiro Hoffman (2016: 601) has framed EU-Africa relations in terms of 'inter- and transregionalism', defined as 'state and non-state actordriven processes of bridging regions both institutionally and socially'. Interregionalism refers to the relations between formal regional organizations, while transregionalism is a residual category pointing at less formalized relations between regions and the involvement of non-state actors. An example of interregionalism is the relationship between the EU and SADC, while transregional relations can be illustrated by the EU-Africa Dialogue (Ribeiro Hoffmann 2016: 602). According to Ribeiro Hoffmann (2016: 606-607), a successful account of inter- and transregional relations needs to rest on a combination of EU foreign policy analysis with notions of norm diffusion, the former emphasizing the EU's interests and the latter focusing on the EU's wish to 'export' its norms and values.

\section{ACTORS IN REGIONALISM}

The range of actors involved in regionalism is probably as diverse as in any other area of inter- and transnational relations. In order to provide a succinct discussion of the variety of actors, we focus on states, domestic actors and individual action.

\section{States}

Despite the fact that scholars have paid attention to a broad variety of actors in regionalism, states remain the central focus of most analyses. Börzel (2016: 42) argues that the state-oriented nature of many approaches to regionalism is a consequence of their focus on the establishment of formal institutions for enhancing interstate cooperation, importantly related to trade, investment or security. Further, she relates the focus on the state to the prominent place of European integration in the field of regionalist studies. Important theories of international relations that have 
been applied to regionalism share this orientation on the state (see Börzel 2016: 44 46; Hout 1999: 14-18). For instance, neo-realist approaches focus on power relations among states and emphasize the role of powerful states (or 'hegemons') in the establishment of regionalist frameworks. In this regard, Grieco (1997: 173) has argued that: 'we should observe regionalism developing more fully in those areas of the world in which there is a local hegemon able to create and maintain regional economic institutions, and we should observe regionalism advancing at a less pronounced pace in those areas where local hegemonic leadership is less visible'.

Neo-liberal institutionalism, which is usually considered to be neorealism's main theoretical competitor, provides a different analysis of the sources of regionalism, but shares its state-centric focus. Neo-liberal institutionalists analyse regionalist frameworks as a specific sub-category of international regimes - 'sets of implicit or explicit principles, norms, rules, and decision-making procedures around which actors' expectations converge in a given area of international relations' (Krasner 1983: 2) - and focus their analysis of cooperative arrangements on shared interests among states. Regionalist schemes provide public goods that states cannot deliver on their own: in particular, coordination and information-sharing are important public goods in a situation of complex interdependence and globalization (Keohane 1984: 85-109).

Neo-functionalism, which originated as one of the earlier approaches in studying the process of European integration, shares many assumptions with neo-liberal institutionalism, and has a similar focus on the state as the main actor in regionalism. Neo-functionalists, such as Ernst Haas (1958), agree with neo-liberal institutionalists that enhanced interdependence among countries increases the likelihood of cooperation. As pointed out in an earlier section, neo-functionalists expect that policy-makers will appreciate the benefits of regional cooperation, and that policy coordination will 'spill over' from one issue area to another, thus bringing about deeper integration and pooling of sovereignty.

\section{Domestic Actors}

As processes of regionalism evolved over time, analysts have become increasingly sceptical about state-centric explanations of regional cooperation. In particular since the rise of 'new regionalism', many scholars have turned to analysing the influence of domestic actors on a range of regional dynamics.

A classic in the literature on regionalism, Axline's (1977) analysis pointed to the difficulties experienced by what he calls 'underdeveloped countries' in realizing more profound regionalist schemes. Although particular forms 
of integration would seem to be particularly beneficial for developing countries, as they include 'measures to overcome or reduce the pattern of dependence on metropolitan countries' (Axline 1977: 88), such forms are also the most the most difficult to achieve. In his explanation of the difficulties involved in the establishment of deeper economic integration, Axline pays attention to the distribution of the costs and benefits of such schemes across countries as well as sub-national actors. He indicates that the support for regionalism will generally be less in developing countries than in industrialized ones, as ' $[\mathrm{t}]$ here is likely to be ... a period of uncertainty and instability preceding the point at which this favorable distribution of opportunity costs occurs, and in integration schemes among underdeveloped countries this time period is likely to be much longer than in industrialized regions' (Axline 1977: 104).

Various scholars from the neo-liberal institutionalist tradition have been important in analysing societal or domestic forces involved in the process of regional cooperation. In an early attempt to move the explanation of European integration away from prevalent state-centrism, Andrew Moravcsik (1993) adapted the 'two-level games' approach to international relations (cf. Putnam 1988) to decision-making in the European Community/Union. Moravcsik (1993: 480) argues that a so-called 'liberal intergovernmentalist' approach is required for understanding regional policy coordination: its 'substantive and institutional development ... may be explained through the sequential analysis of national preference formation and intergovernmental strategic interaction'. In this view, the negotiation process among governments is clearly important, but the outcome of such interactions is dependent on the preferences of domestic groups that either derive benefits from international agreements or are hurt by them.

The liberal intergovernmentalist approach to regional cooperation was generalized further by Helen Milner, who argued that regionalism needs to be understood as the outcome of a process of demand and supply. The 'demand' is exercised by domestic groups, who prefer the benefits of policy coordination, while the 'supply' of regional arrangements is the task of national governments. The pressure to conclude regional trade agreements increases when firms become more dependent on trade, firms become more active internationally, or trade composition shifts from inter- to intra-industry trade (Busch and Milner 1994: 268). Firms that benefit from economies of scale will exert pressure on their government to establish regional free trade schemes (Milner 1997: 80-86). Mattli's (1999) 'institutional approach', which was addressed above in relation to the material drivers of regionalism, focuses on demand and supply conditions in a comparable way. In this case, demand conditions relate to the gains that 
are to be expected from market integration and the costs of international trade and investment. Supply conditions relate to the pay-offs derived from integration by the political leaders and the presence of undisputed leaders (Mattli 1999: 46-47).

The role of 'domestic coalitions' in regionalism is a central element of the analysis of Solingen (2015: 35-90), Solingen and Malnight (2016) and Ravenhill (2016). Solingen and Malnight (2016: 68-69) distinguish between two ideal-typical coalitions: internationalizing and inward-looking ones. In their view, regionalisms are shaped by the nature of the domestic coalition that becomes dominant: 'the nature of dominant coalitions explains incentives to create institutions, mold them according to their preferences and fine-tune their effects' (Solingen and Malnight 2016: 76). In a similar way, Ravenhill's (2016: 46) analysis of the circumstance that 'African regional economic institutions often appear to be designed to fail' revolves around the weakness of outward-oriented, internationalizing coalitions. According to Ravenhill (2016: 43), '[i]nward-looking, rent-seeking coalitions that frequently dominate the political scene in Africa are likely to derail the regionalism project' (Ravenhill 2016: 43). In his view, functional and political forms of regionalism seem to be successful because they have limited impact on the policy autonomy of the state. Deeper forms of economic regionalism, on the other hand, are often preached, but hardly practiced, precisely because of their impact on state autonomy. Thus, economic regional cooperation rarely ever surpasses the level of the free trade area (Ravenhill 2016: 40).

Non-state actors have figured prominently in the so-called world order approach. This approach, which draws on neo-Gramscian theories of international political economy (developed by, among others, Cox 1987), focuses on 'historical structures, defined as configurations of forces (material capabilities, ideas and institutions) which do not determine actions but nevertheless create opportunities and impose constraints' (Gamble and Payne 2003: 46). The Gramscian notion of hegemony, which refers to political dominance produced by a combination of coercion and ideological consent, is key to the creation and maintenance of forms of world order, including regionalist frameworks. In order to garner support for regional frameworks, which currently are mainly built to promote the liberalization of trade and investment, social forces have taken recourse to neo-liberal arguments about the limitation of state control and the importance of market-led economic growth (Payne and Gamble 1996: 15-18; Gamble and Payne 2003: 51-53; Zajontz and Leysens 2015: 306-308). The world order approach sees non-state actors (or 'civil society') both as potential carriers of dominant ideologies in support of regionalist projects, and as possible contesters of those projects. In the latter case, non-state 
actors may become the source of counter-hegemony and support alternative pathways that oppose the dominant approach.

In their analysis of regionalism in Southern Africa, Zajontz and Leysens (2015: 309) focus on the dominant neo-liberal regionalist project, which revolves around the liberalization of economic relations in the region. The neo-liberal project is driven by 'regional state-business partnerships', involving outward-oriented South African corporations in alliance with political elites in the neighbouring countries. Zajontz and Leysens (2015: 316) see 'regional civil society' as a potential force to counter undesirable developments in the continent, for example in relation to the economic practices of emerging powers such as China and India. In their view, civil society is possibly a constructive force for the development of counterhegemonic alternatives:

[A]ll over Africa civil society actors regularly protest against economic practices of emerging powers, which they consider, amongst others, disadvantageous for local development or the environment - ranging from public condemnation to riots. Given the lack of political will among African decision-makers to come up with collective and harmonized regional strategies vis-à-vis emerging powers, the role of regional civil society actors in pressing for and advancing inclusive regional approaches for the engagement with external actors becomes pivotal. Developing regionalisms become a crucial regional instrument to react to changing social, economic and political circumstances on the continent. (Zajontz and Leysens 2015: 316)

Neo-Marxist analyses of regionalism in Southern Africa, such as Van der Merwe's (2016) account revolving around the history of South Africa's system of accumulation, focus on the private sector and their interaction with governments. Van der Merwe (2016: 63) analyses regional arrangements, both in the period of British rule and afterwards, as part of processes of regional accumulation, where '[t]he emergent South African bourgeoisie consciously sought to integrate the regional economy through processes of uneven and combined development'. In his interpretation, the region has been serving Afrikaner capital as a source of minerals and labour, not only leading to the exploitation of black labourers in South Africa - later institutionalized under apartheid - but also elsewhere by the setting up of a system of migrant labour (Van der Merwe 2016: 65-68).

\section{Individual Action}

Importantly, a number of scholars have paid attention to the action of individuals in the context of regionalism. In particular, this focus has led to the analysis of manifestations of informal and trans-state regionalism, which were described in an earlier section. Authors such as Clapham 
(1999), Bach (2016b: 70-75), Söderbaum (2016b: 79-97) and Taylor (2003: 321-325) have focused on the way in which actors, operating individually or in groups, have set up informal networks across borders. They emphasize how informal activities are undertaken by 'a mosaic of informal workers, self-employed agents, families, business networks, petty traders, migrant labour, refugees, and so forth' (Söderbaum 2016b: 89). Usually, these groups make use of opportunities that are created by existing formal regional frameworks, and sometimes they operate in conjunction with the state, as in Bach's (2016a: 75) trans-state networks. Taylor's (2003: 322-323) analysis of the Maputo Development Corridor, spanning the South African-Mozambican border area, is an illustration of how private sector-driven 'spatial development initiatives' may be useful for informal and illegal activities, related to drug and weapon smuggling, counterfeiting money and labour migration.

\section{CONCLUSION}

The discussion in this chapter has attempted to understand how the scholarly literature has conceptualized regionalism, and which drivers and actors it has identified in the process of region-building. Conceptually, an important distinction has been made between regionalism and regionalization, where the former concept denotes a mainly de jure process of region formation, while the latter refers to a de facto process of intensifying relationships of various sorts across a geographical area. A subsequent section, on the ontology of regions and regionalisms, concluded that regions should be understood not as fixed entities, but rather as variable responses to a changing environment, where political, economic and social considerations are co-determinants of regionalist strategies. As to the drivers of regionalisms, we identified a variety of factors that play a role in the building of regions. We grouped these drivers into four categories: material, ideational, political and external. These drivers have been found to operate either individually or in interaction across various regionalist practices. Finally, the chapter focused on the actors in regionalism: here we identified states, domestic actors and individual action, and discussed how particular theoretical perspectives privilege the role of some of these actors over others in regional frameworks.

The next chapters build on the insights of the literature on comparative regionalism that were summarized above. Chapter 2, which discusses the evolution of African regionalisms, focuses mainly on the ideational drivers of representatives of African states in emphasizing the need for collaboration across the continent. The chapter analyses the emergence 
of pan-Africanism as an ideological and emotional force characterizing the epoch of decolonization, and discusses the ensuing attempts of building sub-regional entities to deal with common problems. Chapters 3 and 5 focus on asymmetries in development across African regions and on intra-African trade, and highlight the importance of material in contrast to ideational drivers, and of domestic, private sector actors in contrast to states. The material drivers relate to the interest in bringing about economic transformation on the continent, aiming to stimulate self-reliance, among others by attempting to create bigger regional markets or, more recently, aiming to establish a continent-wide free trade area. Chapter 4, which concentrates on issues of peace, conflict, governance and democracy, discusses a variety of political drivers, relating mainly to state-based actors, but increasingly also to civil society action. The chapter pays explicit attention to conflict management instruments, as exemplified in the institutionalization of the African peace and security architecture. Chapter 6, on the global embedding of Africa's trade, investment and aid relations, focuses on external drivers and highlights old and new (statebased and private sector) partners, ranging from Western countries and the European Union, to emerging countries such as China and India.

\section{NOTE}

1. This chapter is not the place to provide a full account of the scholarly literature on regionalism. Overviews of different approaches have been provided recently by, among others, Börzel (2016), Shaw et al. (2011), Söderbaum (2016a, 2016b) and Wiener and Diez (2009). Various older works - such as Farrell et al. (2005), Hout (1999), Hurrell (1995), Laursen (2003) and Söderbaum and Shaw (2003) - also provide overviews of approaches to regionalism that are still relevant for today's discussions on the topic. 